\title{
Enzyme Activity Changes during Cyclic AMP-induced Stalk Cell Differentiation in P4, a Variant of Dictyostelium discoideum
}

\author{
By I. D. HAMILTON* AND W. K. CHIA† \\ Department of Biology, Princeton University, \\ Princeton, New Jersey 08540, U.S.A. \\ (Received 7 March 1975; revised 25 June 1975)
}

\begin{abstract}
SUMMARY
The P4 variant of Dictyostelium discoideum is characterized by the production of fruiting structures in which the overall proportion of stalk to spore material is increased, relative to the wild type. The altered morphology of the mutant is due to increased sensitivity to cyclic AMP which promotes stalk cell differentiation. In the presence of $\mathrm{IO}^{-4} \mathrm{M}$-cyclic AMP the entire population of $\mathrm{P4}$ amoebae forms clumps of stalk cells on the surface of the dialysis membrane support.

Measurement of changes in activity of a range of developmentally-regulated enzymes during the development of P4 in the presence and absence of cyclic AMP has allowed us to identify three classes of enzyme: (i) Those, such as $\beta$-glucosidase II, trehalose-6-phosphate synthetase and uridine diphosphogalactose-4-epimerase, which are required for the production of spores. (ii) Enzymes, primarily but perhaps not exclusively, required during stalk cell formation. Typical of these are $N$-acetylglucosaminidase and alkaline phosphatase. (iii) General enzymes, such as threonine dehydrase, $\alpha$-mannosidase and uridine diphosphoglucose pyrophosphorylase, which are present in both pre-stalk and pre-spore cells and appear to be necessary for the development of both cell types.
\end{abstract}

\section{INTRODUCTION}

Changes in enzyme specific activities during the development of the cellular slime moulds have been studied to understand the biochemical mechanisms underlying development. Sussman and his co-workers (for a review, see Sussman \& Sussman, 1969) have focused their attention on the role of transcription and translation of enzymes while Wright (1966, 1972) and her associates look to the role of enzyme substrates and products in the chemical control of development. As has been pointed out (Francis, I969; Bonner, I97I; Newell, 197I), there is no conflict between these two proposed mechanisms and it is reasonable to assume that both play a role in development.

Development leads to the production of both stalk cells and spores and these exhibit different metabolic activities during development. By dissection of individual slugs, Newell, Ellingson \& Sussman (1969) demonstrated that different programmes of enzyme synthesis occurred during the development of stalk cells and spores. This approach is however limited to that period in development when pre-stalk and pre-spore cells are separable in the aggregate, and does not allow either to be examined throughout development. Since a separation of spore cell development from stalk cell development is possible in the variant $\mathbf{P} 4$, we have used it in our studies. In the development of $\mathbf{P} 4$ there is both stalk cell and spore differentiation, but in the development of $\mathrm{P} 4$ amoebae with $\mathrm{IO}^{-4} \mathrm{M}$ -

* Present address: Department of Biochemistry, University of Glasgow, Glasgow G12 8QQ.

$\dagger$ Present address: Singapore Science Centre, Singapore 5, Singapore. 
cyclic AMP (c-AMP), all the amoebae are shifted to one pathway of development: stalk cell differentiation.

Eight enzymes, $\beta$-glucosidase, $\alpha$-mannosidase, $N$-acetylglucosaminidase, alkaline phosphatase, threonine dehydrase, uridine diphosphoglucose pyrophosphorylase (UDPglucose pyrophosphorylase) uridine diphosphogalactose-4-epimerase (UDPgalactose-4-epimerase) and trehalose-6-phosphate synthetase, were selected in this study. They have been studied by previous authors who suggested that they are part of the developmental programme in cellular slime moulds (Coston \& Loomis, 1969; Loomis, 1969 $a, b$, 1970a, $b$; Newell \& Sussman, 1970; Telser \& Sussman, 1971; Newell, Franke \& Sussman, 1972). The selection of such a wide spectrum of enzymes was chosen to cover a range of different metabolic functions which are expressed at different times during development.

\section{METHODS}

Organisms. A variant of Dictyostelium discoideum, strain NC4, haploid (DdH), was used in these experiments. The variant, known as Petite-4, was produced by ultraviolet irradiation (Hohl \& Raper, I964). This strain was kindly given to us by Professor Hohl and has been kept in our laboratory for 8 years during which time it has clearly gone through some further modification and therefore will be referred to as $\mathrm{P} 4$ to distinguish it from the original variant, Petite- 4 .

The amoebae of $\mathrm{P} 4$ were grown with Escherichia coli $\mathrm{B} / \mathrm{r}$ on $0 . \mathrm{I} \%$ lactose-peptone agar (Bonner, 1967). After $36 \mathrm{~h}$ of incubation at $2 \mathrm{I} \pm \mathrm{I}{ }^{\circ} \mathrm{C}$, the amoebae grew to $10^{7}$ cells per Petri dish $(100 \times 15 \mathrm{~mm})$ containing $35 \mathrm{ml}$ of $0.1 \%$ lactose-peptone agar. These were harvested by centrifugation as described by Bonner (1947).

Chemicals. The reagents used in the enzyme assays were glucose-6-phosphate dehydrogenase, lactic dehydrogenase, phosphoglucomutase and pyruvate kinase from Boehringer, Mannheim, Germany, bicine [ $N, N$-bis(2-hydroxyethyl)glycine], $p$-nitrophenyl phosphate, tricine [ $N$-tris(hydroxyethyl)methyl-glycine] and uridine diphosphogalactose from Calbiochem, bovine serum albumin from Mann Research Laboratories, New York, N.Y., U.S.A., and 2,4-dinitrophenyl hydrazine, glucose-6-phosphate, nicotinamide adenine dinucleotide, nicotinamide adenine dinucleotide (reduced form), nicotinamide adenine dinucleotide phosphate, pyridoxal phosphate, threonine, uridine diphosphoglucose and uridine diphosphoglucose dehydrogenase from Sigma.

Drums. Two sizes of drums were used, 8 and $4.5 \mathrm{~cm}$ in diameter, which would 'hold' $8 \times 10^{7}$ and $2.5 \times 10^{7}$ cells respectively on the upper surface of the cellophane membrane. The large drum was placed on a $5 \times 9 \mathrm{~cm}$ crystallizing dish containing $80 \mathrm{ml}$ of $\mathrm{I} \%(\mathrm{v} / \mathrm{v})$ Bonner's salt solution $\left(6 \mathrm{mg} \mathrm{NaCl}, 7.5 \mathrm{mg} \mathrm{KCl}\right.$ and $3 \mathrm{mg}$ of $\mathrm{CaCl}_{2}$ in I 1 distilled water; Bonner, 1947), and the small drum in a crystallizing dish containing $30 \mathrm{ml}$ of I \% Bonner's salt solution. The drum is a device used for acrasin collection (Konijn et al. 1968) and for supporting the development of cellular slime moulds (Chia, I975).

After harvesting, the vegetative amoebae of $\mathrm{P} 4$ were suspended in $50 \%(\mathrm{v} / \mathrm{v})$ Bonner's salt solution and added to the upper surface of the dialysis membrane fitted in the two halves of the drum. After allowing $20 \mathrm{~min}$ for all the cells to settle and attach to the surface of the dialysis membrane, the excess $50 \%$ salt solution was poured off so that amoebae were in an air-water interface and development could proceed.

Two groups of drums were prepared for each experiment. One set contained I \% Bonner's salt solution in the crystallizing dish (control); in these, P4 cells on top of the dialysis membrane developed normally, giving the three types of fruiting bodies charac- 
Table I. Enzyme extraction and assay procedures

\begin{tabular}{|c|c|c|c|}
\hline Enzyme & Resuspension medium & $\begin{array}{l}\text { Extraction } \\
\text { procedure }\end{array}$ & Assay procedure \\
\hline$\beta$-Glucosidase & $\mathrm{H}_{2} \mathrm{O}(3 \mathrm{ml})$ & $\begin{array}{l}\text { Coston \& Loomis } \\
\text { (I969) }\end{array}$ & $\begin{array}{l}\text { Coston \& Loomis } \\
\text { (1969) }\end{array}$ \\
\hline$N$-acetylglucosaminidase & $\mathrm{H}_{2} \mathrm{O}(3 \mathrm{ml})$ & $\begin{array}{l}\text { Coston \& Loomis } \\
\text { (1969) }\end{array}$ & Loomis (I969a) \\
\hline$\alpha$-Mannosidase & $\mathrm{H}_{2} \mathrm{O}(3 \mathrm{ml})$ & $\begin{array}{l}\text { Coston \& Loomis } \\
\text { (I969) }\end{array}$ & Loomis (1970a) \\
\hline Threonine dehydrase & $\mathrm{H}_{2} \mathrm{O}(3 \mathrm{ml})$ & $\begin{array}{l}\text { Coston \& Loomis } \\
\text { (1969) }\end{array}$ & Loomis $(1970 b)$ \\
\hline Alkaline phosphatase & $\mathrm{H}_{2} \mathrm{O}(3 \mathrm{ml})$ & $\begin{array}{l}\text { Coston \& Loomis } \\
\text { (I969) }\end{array}$ & Loomis $(1969 b)$ \\
\hline UDPglucose pyrophosphorylase & $\begin{array}{l}20 \%(\mathrm{v} / \mathrm{v}) \text { glycerol in } 0 . \mathrm{I} \mathrm{M}- \\
\text { tricine- } \mathrm{NaOH}, \mathrm{pH} 7.5 \\
(1.5 \mathrm{ml})\end{array}$ & $\begin{array}{l}\text { Newell et al. } \\
(1972)\end{array}$ & $\begin{array}{l}\text { Newell \& } \\
\text { Sussman (I970) }\end{array}$ \\
\hline UDPgalactose-4-epimerase & $\begin{array}{l}20 \%(\mathrm{v} / \mathrm{v}) \text { glycerol in } 0.1 \mathrm{M}- \\
\text { tricine-NaOH, pH } 7.5 \\
(\mathrm{I} .5 \mathrm{ml})\end{array}$ & $\begin{array}{l}\text { Newell et al. } \\
\text { (I972) }\end{array}$ & $\begin{array}{l}\text { Telser \& } \\
\text { Sussman (I97I) }\end{array}$ \\
\hline $\begin{array}{l}\text { Trehalose-6-phosphate } \\
\text { synthetase }\end{array}$ & $\begin{array}{l}0.5 \mathrm{~mm} \text {-sodium thioglycollate } \\
\text { in } 0.01 \mathrm{M} \text {-tris- } \mathrm{HCl} \mathrm{pH} 7.5 \\
(\mathrm{I} \mathrm{ml})\end{array}$ & $\begin{array}{l}\text { Newell et } a \text {. } \\
\text { (1972) }\end{array}$ & $\begin{array}{l}\text { Newell et al. } \\
(1972)\end{array}$ \\
\hline
\end{tabular}

teristic of the P4 variant (Chia, 1975). The other set contained $10^{-4} \mathrm{M}-\mathrm{C}-\mathrm{AMP}$ in $\mathrm{I} \%$ Bonner's salt solution and induced $100 \%$ stalk cell development. Samples were removed from both sets of drums at intervals for enzyme assay.

Harvesting of cells for enzyme assays. Three $\mathrm{ml}$ of $\mathrm{I} \%$ Bonner's salt solution were added to the upper surface of the drum to wash off the amoebae. After putting a small drop on a glass slide for morphological observation, the cell suspension was transferred to a $13 \mathrm{~mm}$ test tube and centrifuged at I I00 $\mathrm{g}$ for I min. The supernatant was discarded and the cell pellets harvested from each drum were resuspended in one of three solutions, depending on the enzymes to be assayed (Table I). All samples were then frozen in dry ice-ethanol mixture and stored at $-20{ }^{\circ} \mathrm{C}$.

Preparation of cell extracts and measurement of enzyme activities. Extracts were prepared and enzymes assayed in the stored samples as described (Table I). All extinction measurements were made using a Cary model I 4 spectrophotometer. Enzyme activity was expressed as enzyme units/mg protein, where I enzyme unit was that activity required to transform I $\mathrm{nmol}$ substrate/min under the conditions of the assay. Protein was determined by the method of Lowry et al. (195I) using bovine serum albumin as a standard.

\section{RESULTS}

\section{Timing of development of $\mathrm{P} 4$ on the drum}

First it is important to describe the morphological changes of the P4 amoebae with time, both in the presence and the absence of added c-AMP. After harvesting the P4 amoebae from the growth plates and placing them on the dialysis membrane of the drum, their development was well synchronized. The stages of development occurred at consistent times in successive experiments. The time sequence for development of P4 with and without c-AMP is summarized in Fig. I, using data obtained from photomicrographs (Chia, 1975), and the essential differences are summarized in Table 2. 
Table 2. Development of $\mathrm{P} 4$ on the drum, in the absence and presence of $c-A M P$

The cells were placed on the drum at time zero.

\begin{tabular}{|c|c|c|c|}
\hline \multicolumn{2}{|c|}{ Control } & \multicolumn{2}{|c|}{ With c-AMP } \\
\hline Time (h) & Stage & Time (h) & Stage \\
\hline $0-6$ & Pre-aggregation & $0-8$ & Amoebae remain solitary \\
\hline $6-10$ & Aggregation & $8-15$ & $\begin{array}{l}\text { Clumping of amoebae; } \\
\text { no true aggregation }\end{array}$ \\
\hline $10-14$ & $\begin{array}{l}\text { Late aggregation; } \\
\text { formation of } \\
\text { pseudoplasmodia }\end{array}$ & $15-20$ & $\begin{array}{l}\text { Clumps becoming more } \\
\text { clearly defined; amoebae } \\
\text { remain undifferentiated }\end{array}$ \\
\hline $14-I 8$ & Migration & 20 & $\begin{array}{l}\text { Beginning of stalk cell } \\
\text { differentiation at the } \\
\text { periphery of the clumps }\end{array}$ \\
\hline $18-20$ & Preculmination & $20-30$ & Stalk cell differentiation \\
\hline $20-28$ & Culmination & & $\begin{array}{l}\text { progressing towards } \\
\text { the centre of each clump }\end{array}$ \\
\hline $28-30$ & $\begin{array}{l}\text { Development } \\
\text { complete }\end{array}$ & 30 & $\begin{array}{l}\text { Differentiation of stalk } \\
\text { cell complete }\end{array}$ \\
\hline
\end{tabular}

When the $\mathrm{P} 4$ development under control conditions is completed, the three kinds of fruiting bodies characteristic of the P4 variant are always formed: normal fruiting bodies with a thin stalk and spores; fruiting bodies with spores and a thickened stalk; and stalk cell bumps consisting entirely of stalk cells. However, when the P4 develops in the presence of c-AMP, all the amoebae differentiate into stalk cell bumps.

(a)
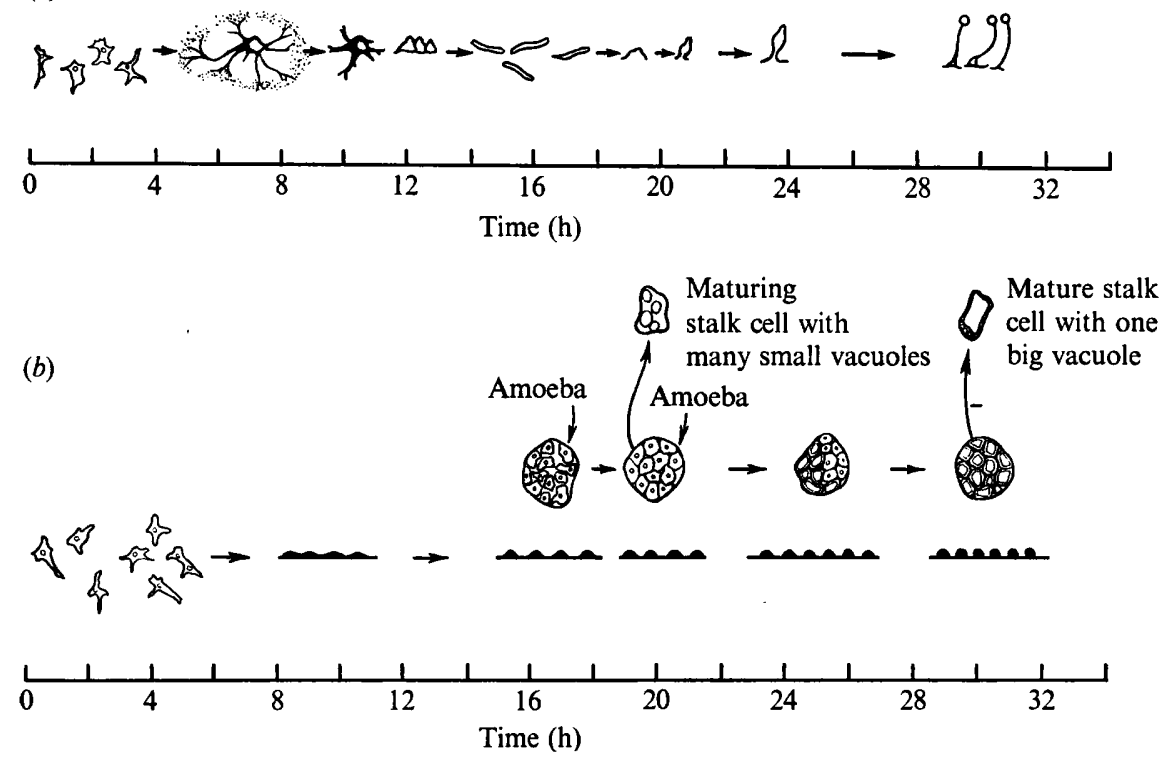

Fig. I. Development of $\mathrm{P} 4$ on dialysis membrane. (a) Control, with $1 \%$ Bonner's salt solution; $(b)$ with $10^{-4} \mathrm{M}$-c-AMP. 

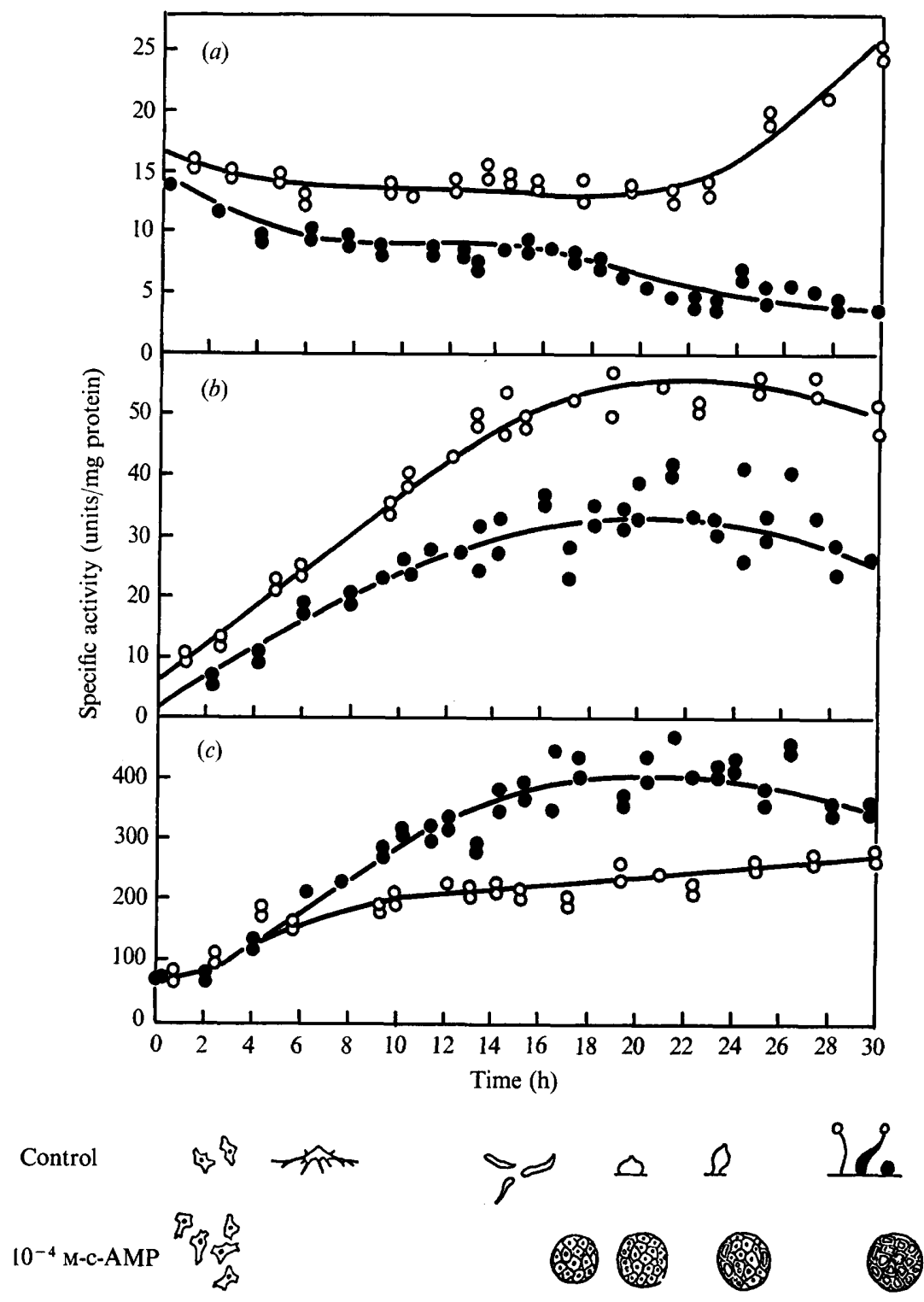

Fig. 2. Changes in the activity of carbohydrate hydrolytic enzymes during the development of the P4 variant. (a) $\beta$-Glucosidase; (b) $\alpha$-mannosidase; (c) $N$-acetylglucosaminidase. $O$, Control; , with $10^{-4} \mathrm{M}-\mathrm{c}-\mathrm{AMP}$.

\section{Changes of enzyme activities during development with and without $c-A M P$}

$\beta$-Glucosidase. The changes in the specific activity of $\beta$-glucosidase are shown in Fig. $2(a)$. In the control, enzyme activity was high when cells were harvested just before the food supply had been depleted. The specific activity decreased slightly through aggregation until the end of migration, then rose again during culmination to reach a maximum when the types of maturing fruiting bodies were formed. In the presence of $10^{-4} \mathrm{M}-\mathrm{c}-\mathrm{AMP}$, the activity of $\beta$-glucosidase decreased throughout development. When development was completed at $30 \mathrm{~h}$, the activity of $\beta$-glucosidase in the presence of c-AMP was six times lower than in the control. 

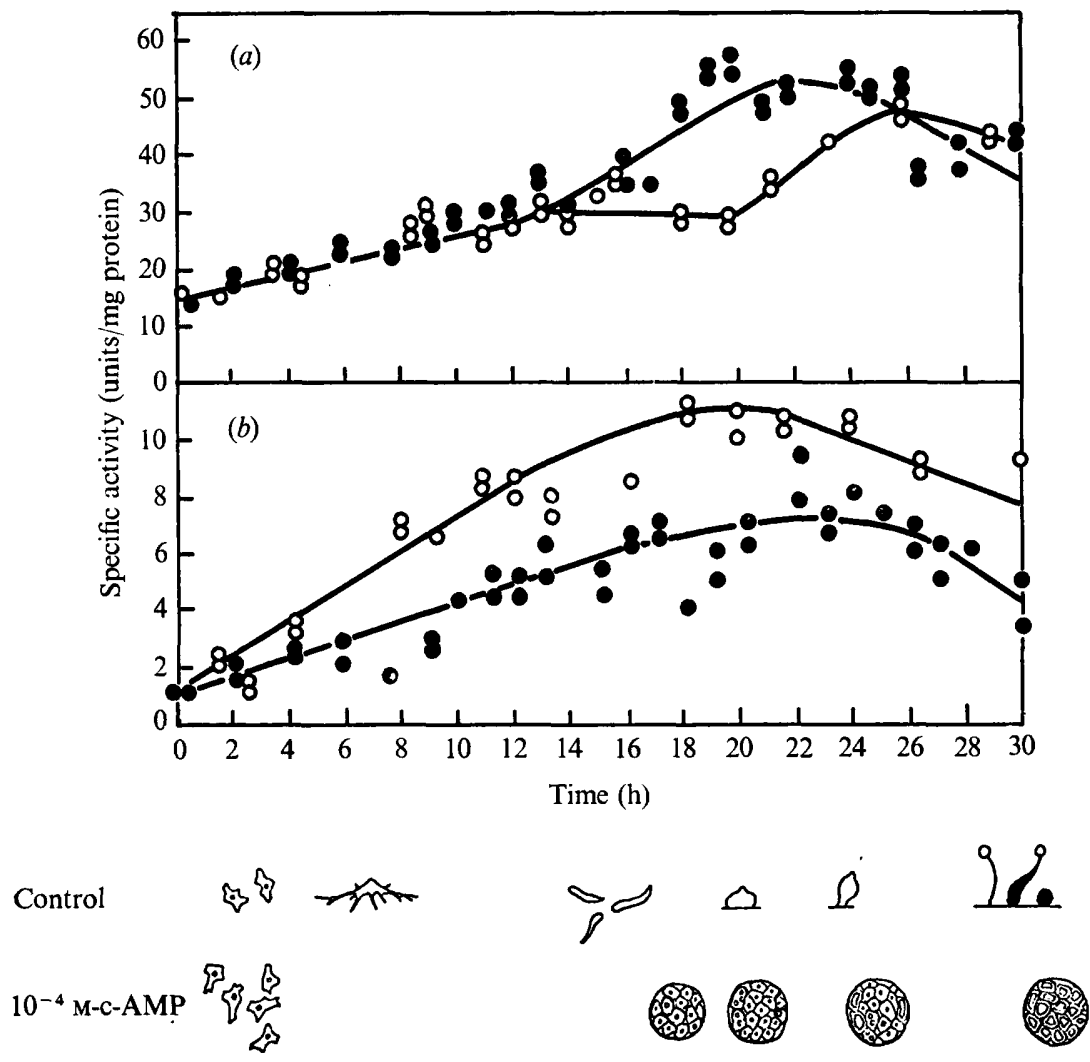

Fig. 3. Changes in the activity of alkaline phophatase $(a)$ and threonine dehydrase $(b)$ during development of the P4 variant. For symbols, see Fig. 2.

$\alpha$-Mannosidase. In the control, the activity of $\alpha$-mannosidase was low when the P4 amoebae were harvested at the late vegetative stage, and then increased through the stages of pre-aggregation and aggregation, reaching a maximum activity when pseudoplasmodia were formed. Thereafter, $\alpha$-mannosidase activity remained constant during culmination and then dropped slightly when mature fruiting bodies were formed. In the presence of c-AMP, the pattern of changes of $\alpha$-mannosidase activity was similar to the control except that at all stages the specific activity was lower (Fig. $2 b$ ).

$N$-acetylglucosaminidase. The time course of $N$-acetylglucosaminidase activity differed strikingly between the control and cultures with c-AMP. In the control there was a rapid initial increase in activity, which fell to a much lower rate once aggregation was complete. In contrast, in the presence of c-AMP the activity of the enzyme increased at the initial rate for $20 \mathrm{~h}$, reaching a maximum at the same time as stalk cells began to appear, and then fell slightly. After $8 \mathrm{~h}$ of development the enzyme activity in the presence of c-AMP was always significantly higher than in the control (Fig. 2c).

Alkaline phosphatase. Treatment with c-AMP also changed the time course of alkaline phosphatase activity in $\mathbf{P} 4$. In the control, the activity increased to an early peak during aggregation, levelled off during pseudoplasmodia formation and early migration, and then increased again reaching a maximum in culmination. With c-AMP, there was no decrease during the first Io to I5 h; rather, the enzyme activity rose continuously to a single peak at $20 \mathrm{~h}$ when the stalk cells were forming (Fig. $3 a$ ). 


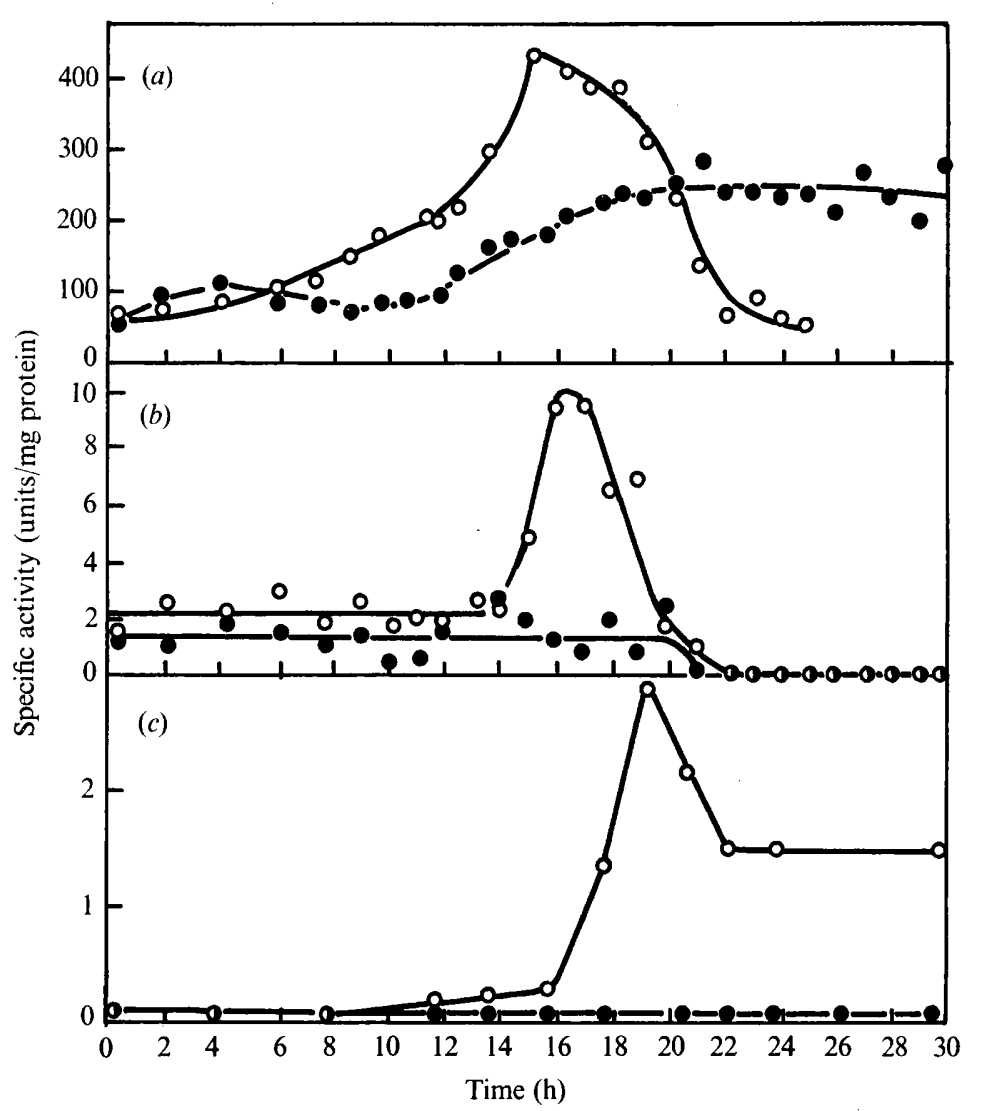

Control

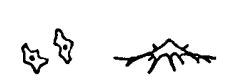

$\rightarrow \infty 0 \Omega$

9.8

$10^{-4}$ M-c-AMP Pि

Fig. 4. Changes in the activity of carbohydrate biosynthetic enzymes during the development of the P4 variant. (a) UDPglucose pyrophosphorylase; (b) UDPgalactose-4-epimerase; $(c)$ trehalose6-phosphate synthetase. For symbols, see Fig. 2.

Threonine dehydrase. The time course of threonine dehydrase activity is shown in Fig. $3(b)$. In the control, the enzyme accumulated and reached a broad peak during the migration stage, and then declined when fruiting bodies were formed. When c-AMP was added, the activity of threonine dehydrase also increased but to a lesser extent. The activity then dropped markedly during the terminal phase of stalk cell differentiation.

Uridine diphosphoglucose pyrophosphorylase. In the control, UDPglucose pyrophosphorylase activity rose during aggregation, reached a peak during the migration stage, and then declined to a very low level during culmination. In contrast, the enzyme activity in amoebae treated with c-AMP did not begin to increase until $12 \mathrm{~h}$, and then reached a maximum at $18 \mathrm{~h}$ when the pre-stalk cells were undergoing the formation of small vacuoles (Fig. $4 a$ ). The maximum activity in the presence of c-AMP was significantly 
lower than the peak activity of the control, but it remained at this level throughout the entire process of stalk cell differentiation.

Uridine diphosphogalactose-4-epimerase. The difference shown in the UDPgalactose-4epimerase activity in the presence and absence of c-AMP was most striking. In the control, the enzyme activity was low during the vegetative stage when the amoebae were harvested, remained at this low level until the end of the aggregation stage, increased sharply reaching a maximum at the end of migration, and then decreased to zero activity as the pseudoplasmodia culminated. In the development with c-AMP, the activity of UDPgalactose-4-epimerase in the amoebae remained at the same low level as found in their vegetative stage until $\mathrm{I} 6 \mathrm{~h}$, when it declined to zero. The surge of enzyme activity seen in the control never appeared (Fig. $4 b$ ).

Trehalose-6-phosphate synthetase. The time course of trehalose-6-phosphate synthetase activity in the control was again remarkably different from the development in the presence of c-AMP. The activity remained at zero until the end of aggregation and then increased to a peak at the beginning of culmination. The activity declined gradually during the formation of fruiting bodies. In contrast, trehalose-6-phosphate synthetase activity was not present at all in the development of amoebae supplied with c-AMP (Fig. $4 c$ ).

\section{DISCUSSION}

Cyclic AMP readily induces the formation of vacuolated cells ( $100 \%$ ) in the $\mathrm{P} 4$ variant of $D$. discoideum. We believe these cells to be stalk cells and, although not arranged in a fruiting structure, to be identical to the stalk cells formed during normal development. The major evidence in support of this conclusion comes from photomicrographs which show that the change in morphology of the cells, from the appearance of many small vacuoles to their merger into a large vacuole, coincides exactly with these changes during fruiting body construction (Chia, 1975). The structure of the final vacuolated cells and normal stalk cells are identical when observed in phase-contrast (Fig. 5) or electron microscope photographs (J. T. Bonner, unpublished observation), and birefringence patterns produced by the cell walls of normal stalk cells and c-AMP-induced stalk cells both indicate the presence of cellulose. In addition to the microscopical evidence, there is the effect of c-AMP on fruiting body morphology. The P4 variant, in the absence of added c-AMP, produced abnormal fruiting bodies (Fig. I). Increasing concentrations of c-AMP, added to the medium surrounding the cells, resulted in increasing proportions of stalk cell material in the final fruiting bodies until at $10^{-4} \mathrm{M}-\mathrm{c}-\mathrm{AMP}$ all cells formed clumps on the surface of the dialysis membrane (Fig. I). There was therefore a gradual increase in the proportion of stalk cell material produced as the concentration of c-AMP rose. These findings, many of which are described by Chia (1975), together with the fact that the anterior pre-stalk zone of the pseudoplasmodium is known to secrete more c-AMP

- than the pre-spore region (Bonner, 1949; Maeda \& Maeda, 1974) and has more bound c-AMP (Pan et al. 1974), suggest that these vacuolated cells are indeed stalk cells and that, in normal development, stalk cells might be induced by c-AMP.

We have followed the specific activity changes of a number of enzymes which had been examined by others to see to what extent they might be affected by c-AMP. If c-AMP is indeed the true inducer of stalk cell differentiation, then the result of morphological studies and enzyme assays should at least be parallel and consistent with metabolic changes known to be taking place in pre-stalk and pre-spore cells during normal fruiting body construction. Our approach depended on two observations. First, there is relatively little 


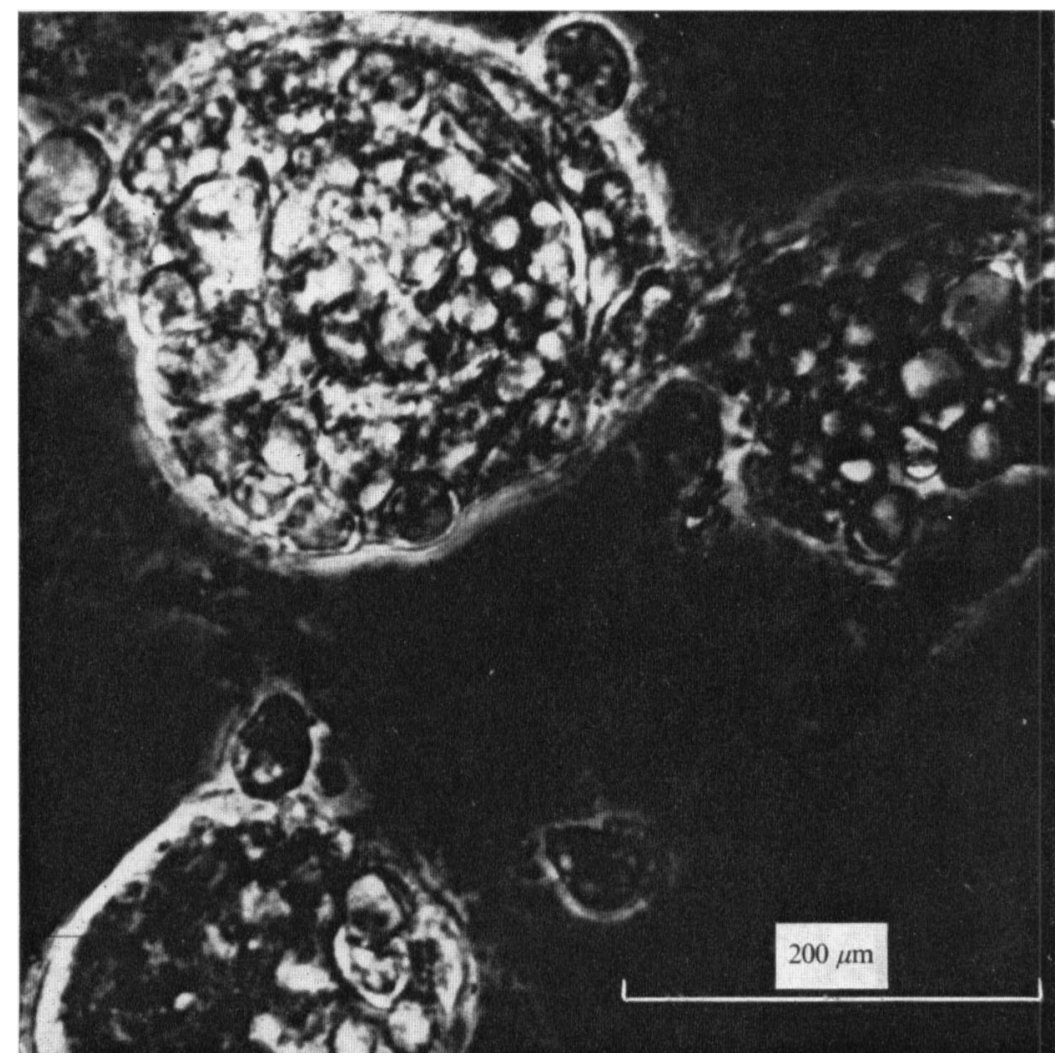

Fig. 5. Phase-contrast photograph of a c-AMP-induced clump of stalk cells. Highly vacuolated cells, produced after exposure of $\mathrm{P} 4$ to $10^{-4} \mathrm{M}-\mathrm{C}$-AMP for $30 \mathrm{~h}$, can be seen at the edge of the clump.

difference in these enzyme activities between the $\mathrm{P} 4$ variant and wild-type $D$. discoideum $(\mathrm{DdH})$; this slight difference could be accounted for either by the slightly lower amount of protein remaining after P4 development (where a higher proportion of lower-protein content stalk cells are produced than in the wild type), or by the altered spore/stalk ratio in the final differentiated state. Secondly, when we compare P4 development with and without c-AMP, we are comparing the differentiation of pure stalk cells and of mixed stalk cells and spores. The differences indicate which enzymes are involved in both stalk cell and spore differentiation, and which are involved solely in stalk cell or in spore differentiation.

On the basis of our results the enzymes measured can be divided into three categories.

(i) Enzymes associated with spore differentiation. Three of the enzymes studied showed changes in specific activity, suggesting that they are exclusively associated with the development of spores. These were trehalose-6-phosphate synthetase (Fig. 4c) and UDPgalactose-4-epimerase (Fig. $4 b$ ), where no activity was detected in the absence of spore formation, and $\beta$-glucosidase II (Fig. $2 a$ ), which has been shown to be associated with the increased $\beta$-glucosidase activity observed late in development (Coston \& Loomis, 1969). All these enzymes fulfil roles which are exclusive to the metabolism of spores: trehalose-6-phosphate synthetase is required for production of trehalose, the spore storage carbohydrate (Clegg \& Filosa, 1961; Ceccarini \& Filosa, 1965), and UDPgalactose-4- 
epimerase for the production of UDPgalactose for synthesis of mucopolysaccharide, a component of the spore coat (White \& Sussman, 1963; Telser \& Sussman, 1971), while $\beta$-glucosidase II is used to hydrolyse cellobiose and cellotriose during spore germination (Rosness, 1968). The observation with UDPgalactose-4-epimerase supports the results of Nestle \& Sussman (1972), who showed that the addition of c-AMP to a culture of developing DdH cells resulted in a marked reduction in synthesis. Our results showed that in the absence of the production of spores these three activities are not present, and it follows that the metabolic role of these enzymes lies exclusively in spore production.

(ii) Enzymes associated with stalk cell differentiation. Of all the enzymes studied, only $\mathrm{N}$-acetylglucosaminidase and alkaline phosphatase (Fig. $2 c$ and $3 a$ ) activities were found to be higher throughout development in the presence of c-AMP than in the control cultures. Since controls contained a considerable quantity of stalk cells, it seems reasonable to suggest that much of the activity of these enzymes observed in the controls was due to the presence of stalk cells. The results are consistent with previous findings on these enzyme activities.

Isolation of mutants with reduced $N$-acetylglucosaminidase activity (Dimond, Brenner \& Loomis, 1973) has suggested that this enzyme plays an active role in maintaining the size of the migrating slug and so is required during early development. During normal development (Fig. 2c), activity stopped increasing when slug migration began. In the presence of c-AMP, migration did not occur and activity continued to rise until the appearance of stalk cells began.

Alkaline phosphatase was similar. It has been shown by histological evidence (Krivanek, 1956; O'Day \& Francis, 1973) that the enzyme is localized in pre-stalk cells during early development and that activity during culmination is also associated with stalk cells near the site of cellulose formation. The changes in activity which we observed were similar, with the initial rise in activity stopping during slug migration and then rising again during culmination. In the presence of c-AMP, however, the initial rate of increase was maintained and maximal activity was achieved before the appearance of stalk cells.

We conclude that both $\mathrm{N}$-acetylglucosaminidase and alkaline phosphatase activities can be produced continuously in pre-stalk cells but that production is prevented in some way during slug migration. A similar suggestion has been put forward by Newell \& Sussman (1970) to explain the interruption of the synthesis of other enzymes during slug migration. The increase in alkaline phosphatase activity is resumed after slug migration because the organism has a continuing requirement for the activity, unlike $N$-acetylglucosaminidase which appears to be needed only during the earlier stages of development.

(iii) General enzymes. The remaining enzymes which we examined were all present at higher activities in the control cultures than with c-AMP cultures (Figs. $2 b, 3 b$ and $4 a$ ). They were present to a significant extent in stalk cells, suggesting that they play a general role in metabolism of both cell types. Carbohydrates and protein are present in all cells and are broken down and resynthesized during development. The higher activities of $\alpha$-mannosidase (Fig. $2 b$ ), threonine dehydrase (Fig. $3 b$ ) and UDPglucose pyrophosphorylase (Fig. $4 a$ ) in control cultures may be necessary, since pre-spore cells quickly develop into spores (Bonner, 1944) and metabolic activity must be high to allow the high rates of synthesis of trehalose and mucopolysaccharide to be achieved (Sussman \& Sussman, 1969). Previous study on UDPglucose pyrophosphorylase activity under similar conditions showed that addition of c-AMP to developing cells of DdH, before the rise of enzyme activity, markedly depresses the rise and produces fruiting bodies similar to those obtained using P4 under our control conditions (Nestle \& Sussman, 1972). 
Conclusions. Clearly, c-AMP induces stalk-cell differentiation and, at the same time, changes in the specific activities of certain enzymes occur. It does not necessarily follow that the stalk cells are induced because the patterns of enzyme activities are changed; these could be quite independent actions of c-AMP. However, since the enzymes that are shut off are such reasonable candidates for spore enzymes, the hypothesis is that the effect of c-AMP on certain enzymes and its ability to produce stalk cells are related.

This conclusion raises a question of fundamental importance. How does c-AMP affect the changes in enzyme activity; does it act directly on the enzymes by activation or inhibition, or does it affect their synthesis at the level of transcription or translation? The diverse nature of the responses suggests that there is no direct, unique mechanism involved.

One of us (I.D.H.) was a postdoctoral fellow supported by the Jane Coffin Childs Memorial Fund for Medical Research. This work was supported by National Science Foundation grant GM 33439, and National Institutes of Health Grant GM I7856. We also benefited from the central equipment facilities in the Biology Department, Princeton University, supported by the Whitehall Foundation.

\section{REFERENCES}

Bonner, J. T. (1944). A descriptive study of the development of the slime mold Dictyostelium discoideum. American Journal of Botany 31, 175-I 82.

BoNNER, J. T. (1947). Evidence for the formation of cell aggregates by chemotaxis in the development of the slime mold Dictyostelium discoideum. Journal of Experimental Zoology 106, I-26.

BonNer, J. T. (1949). The demonstration of acrasin in the later stages of the development of the slime mold Dictyostelium discoideum. Journal of Experimental Zoology 110, 259-271.

Bonner, J. T. (1967). The Cellular Slime Molds, 2nd edn. Princeton, New Jersey: Princeton University Press.

Bonner, J. T. (197I). Aggregation and differentiation in the cellular slime molds. Annual Review of Microbiology 25, 75-92.

Ceccarini, C. \& Filosa, M. F. (1965). Carbohydrate content during development of the slime mold, Dictyostelium discoideum. Journal of Cellular and Comparative Physiology 66, I35-140.

CHIA, W. K. (I975). Induction of stalk cell differentiation by cyclic AMP in a susceptible variant of Dictyostelium discoideum. Developmental Biology 44, 239-252.

ClegG, J.S. \& Filosa, M. F. (196I). Trehalose in the cellular slime mold, Dictyostelium discoideum. Nature, London 192, $1077-1078$.

Coston, M. B. \& Loomis, W. F., Jun. (1969). Isozymes of $\beta$-glucosidase in Dictyostelium discoideum. Journal of Bacteriology roo, $1208-1217$.

Dimond, R. L., Brenner, M. \& Loomis, W. F., JUN. (1973). Mutations affecting $N$-acetylglucosaminidase in Dictyostelium discoideum. Proceedings of the National Academy of Sciences of the United States of America 70, 3356-3360.

FrancIS, D. W. (1969). Time sequence for differentiation in cellular slime molds. Quarterly Review of Biology 44, 277-290.

Hohl, H. R. \& RAPER, K. B. ( I964). Control of sorocarp size in the cellular slime mold Dictyostelium discoideum. Developmental Biology $9, \mathrm{I} 37-\mathrm{I} 53$.

Konijn, T. M., Barkley, D. S., Chang, Y. Y. \& Bonner, J. T. (1968). Cyclic AMP; a naturally occurring acrasin in the cellular slime molds. American Naturalist 162, 225-233.

KrIVANEK, J. O. (1956). Alkaline phosphatase activity in the developing slime mold, Dictyostelium discoideum Raper. Journal of Experimental Zoology 133, 459-480.

Loomis, W. F., JUN. (I $969 a$ ). $N$-acetylglucosaminidase, an early enzyme in the development of Dictyostelium discoideum. Journal of Bacteriology 97, I $149-$ I 154.

Loomis, W. F., JuN. (1969b). Developmental regulation of alkaline phosphatase in Dictyostelium discoideum. Journal of Bacteriology roo, 41 7-422.

Loomis, W. F., Jun. (I970a). Developmental regulation of $\alpha$-mannosidase in Dictyostelium discoideum. Journal of Bacteriology 103, 375-38I.

LoomIs, W. F., JUN. $(1970 b)$. Temporal control of differentiation in the slime mold, Dictyostelium discoideum. Experimental Cell Research 60, 285-289.

Lowry, O. H., Rosebrough, N. J., Farr, A. J. \& Randall, R. J. (I95I). Protein measurement with the Folin phenol reagent. Journal of Biological Chemistry 193, 265-275. 
MAEDA, Y. \& MAEDA, M.(1974). Heterogeneity of the cell population of the cellular slime mold Dictyostelium discoideum before aggregation, and its relation to the subsequent locations of the cells. Experimenta $l$ Cell Research 84, 88-94.

Nestle, M. \& Sussman, M. (1972). The effect of cyclic-AMP on morphogenesis and enzyme accumulation in Dictyostelium discoideum. Developmental Biology 28, 545-554.

Néwell, P. C. (197I). The development of the cellular slime mold Dictyostelium discoideum, a model system for the study of cellular differentiation. In Essays in Biochemistry, vol. 7, pp. 87-126. Edited by P. N. Campbell and F. Dickins. London and New York: Academic Press.

Newell, P. C., Ei.lingson, J. S. \& Sussman, M. (I969). Synchrony of enzyme accumulation in a population of differentiating slime mold cells. Biochimica et biophysica acta 177, 610-614.

Newell, P. C., Franke, J. \& Sussman, M. (1972). Regulation of four functionally related enzymes during shifts in the developmental program of Dictyostelium discoideum. Journal of Molecular Biology $\mathbf{2 8}$, I36-142.

Newell, P. C. \& Sussman, M. (1970). Regulation of enzyme synthesis by slime mold cell assemblies embarked upon alternative developmental programs. Journal of Molecular Biology 49, 627-637.

O'DAY, D. H. \& Francis, D. W. (1973). Patterns of alkaline phosphatase activity during alternative developmental pathways in the cellular slime mold, Polysphondylium pallidum. Canadian Journal of Zoology 5r, 30I-3IO.

Pan, P. C., Bonner, J. T., Wedner, H. J. \& Parker, C. W. (1974). Immunofluorescence evidence for the distribution of cyclic-AMP in cells and cell masses of the cellular slime molds. Proceedings of the National Academy of Sciences of the United States of America 71, 1623-1625.

Rosness, P. A. (1968). Cellulolytic enzymes during morphogenesis in Dictyostelium discoideum. Journal of Bacteriology 96, 639-645.

Sussman, M. \& Sussman, R. (1969). Patterns of RNA synthesis and of enzyme accumulation and disappearance during cellular slime mold cytodifferentiation. Symposia of the Society for General Microbiology 19, 403-435.

TelSER, S. \& SuSSMAN, M. (I97I). Uridine diphosphate galactose-4-epimerase, a developmentally regulated enzyme in the cellular slime mold Dictyostelium discoideum. Journal of Biological Chemistry 216, 2252-2257.

White, G. J. \& Sussman, M. (1963). Polysaccharides involved in slime mold development. II. Water soluble acid mucopolysaccharides. Biochimica et biophysica acta 74, 179-187.

Wright, B. E. (1966). Multiple courses and controls in differentiation. Science, New York 153, 830-837.

Wright, B. E. (1972). Critical variables in differentiation. Englewood Cliffs, New Jersey: Prentice-Hall. 